\title{
LINGUISTIC ERRORS ON NARRATIVE TEXT TRANSLATION USING GOOGLE TRANSLATE
}

\author{
Aria Septi Anggaira \\ Universitas Negeri Jakarta \\ Email: ariasepti@yahoo.com \\ Muhamad Sofian Hadi \\ Universitas Muhammadiyah Jakarta \\ Email: m_sofianhadi@yahoo.com
}

\begin{abstract}
This study aims to identify and analyze errors of language aspects that appear on the machine translator from Google-Translate on narrative texts in English into Indonesian. Based on the results of the analysis, it is showed that the morphological aspects occupy the highest positions in the data summary types of errors, as many as 13 errors. Next is the syntactic aspect for 9 errors, and morphology of for 12 errors. It can be concluded that the translation using Google Translate is not the right solution for someone who wants to translate foreign language text, especially if it is used in the learning process at schools.
\end{abstract}

Keywords: error, language, translation, Google-translate

\section{INTRODUCTION}

Translation is a process of communication between two languages. The point was reiterated the intent or content of the message in the source text that can be understood by the people of the target language. In other words, translation is an activity to understand the text in one language, which is commonly referred to as the source language, and reveals an understanding of literature into other languages, called the target language.

The results of these activities are carried out by a so-called translator is a translation or target text which is commensurate with the source text. A translation cannot easily be produced to be the same as the original due to differences in culture and language support structure within each language.

Translation is a reproduction in the target language that has the closest equivalent messages and proper performance of the source language, the meaning of the first and the second in style (Nida and Taber; 1996, 12). Therefore, the communication through the translation process should produce a translation that has an equivalence of meaning with the source text and the 
reasonableness of the language in the target text.

In other words, the translation is an attempt to convey the message it contained in source language into commensurately (Newmark; 1988, 5). It can be concluded that simply translating the efforts to change a form of the language into another language (the target language) while maintaining aspects of the equivalence of all the elements in it, ie, phrases, clauses, paragraphs, and others, either oral and written.

Translation activity is not something foreign to anyone who is involved in language, especially a foreign language. However, not a few of them are faced with various difficulties related to aspects of language, non-linguistic and cultural. From the aspects of language to an interpreter will inevitably face the problems in finding the equivalent meaning of a word. This is something that can not be avoided because there may not be a matching words between two languages in the aspects of both linguistics and nonlinguistics.

Therefore, the problems faced by an interpreter meanings arise due to differences in the system, both systems morphological, syntactic and semantic contained between the source language and the target language. While non linguistics aspects related with the weak mastery of the target language and translators will be the translation theory and the lack of supporting facilities. In terms of cultural issues, it is too difficult to find a matching word between two different cultures.

Avoiding trouble translate, in the era of sophisticated technology that they no longer flipping through a dictionary, no longer come to the library, but enough to sit down while opening the laptop computer or even with increasingly sophisticated mobile phones. Internet is not something foreign to us as intellectuals. By using the internet anyone can search for and obtain the information he needs quickly without moving from their seats. Internet allows everyone to access information from all over the world anytime and anywhere.

One service that helps Internet users to search for information effectively is Google. Google currently offers a wide range of applications.One of them is Google-Translate. Machine translation of Google is a solution. Machines attached to this Google will help translate text or web pages from one language to another automatically, so that it is helpful when a reader tries to understand the content of a web page.

Currently Google-Translate can translate into more than 50 languages in the world, one of which is from English into Indonesian and vice versa. Google Translation is an example of application of Machine Translation (MT). MT is a 
combination of linguistics with computational science, often referred to as part of the science of computational linguistic. The point of this science tries to make the machine capable of translating one language into another.

In English language teaching at schools, both junior high school or high school, translation plays an important role in the learning process. The translation is done not only by students but also by teachers. Most learners' translation is done with the help of a dictionary or with the are currently popular Google translate. Many teachers still take advantage of the Google translation services. Although we recognize that the results of the translation via Google translate is not yet up but still only tool is to be the best choice for teachers and learners.

From the above phenomenon, the research was conducted in order to determine and then attempt to analyze the aspects of language errors that appear on the machine translator from Google-Translate. The text to be analyzed is a narrative text in English, which is one type of text taught at both junior and senior high school. The selected text is 'Snow White' which is a narrative text that comes from mainland Europe. The text is analyzed using a knife error analysis (error analysis).

\section{THEORITICAL REVIEW \\ Translation}

Translating is the written transfer activity text messages from one language into another language texts (Hoed; 2006: 5). In this case, the translated text is called the source text and a language called the source language. With regard to the translation, the text drafted by the translator is called the target text, and the language is called the target language.

Catford (1965:20) stated translation is the transfer of textual material in one language (the source language) with equivalent textual material in another language (the target language). Nida and Taber (1996: 34) stated "translation is the reproducing message in the source language with natural equivalence in the target language, play through two steps, first, based on the meaning and second based on style". In other words, the translation is to reproduce the message in the source language with their natural equivalents in the target language, in two steps, first, based on the meanings and the second based on the style (the language) it.

Based on some of the above definitions of translation, translation is a section on the relationship between two or more languages that then either transfers the meaning of the source language (SL) into target language (TL). 


\section{Types of Translation}

Translation can be classified into several types. According to Lado(1968; 261-262) translation is not only used for formal purposes, but the translation is also used for informal purposes. Therefore, the translation may occur in two areas, namely in the realm of factual formal translation in literature (literary) in the realm of informal translation.

Larson (1984: 35) stated that translation based translations into shapes (form-based translation) and translation of the meaning-based (meaning-based translation). Examples of forms-based translation are a literal translation, while translating idiomatic translation is an example of the meaning-based translation. Literal translation is the translation of the word per word (word to word translation). This translation is usually used in linguistic translation. In idiomatic translation (idiomatic translation), the translator tries to divert the meaning of source language into target language so that it can be understood easily and naturally. Therefore, the emphasis on the idiomatic translation of the meaning or message is not on words or other lexical items.

Moreover, Newmark (1988:

45-47) classifies translation into eight kinds, namely:

1. Word for word translation

In translating word for word translation, the wording (word- order) source languages is maintained and words in source language translated one by one in accordance with the general meaning, and not taking account of the context.

2. Literal Translation

In this translation, grammatical constructions source (source language) was transferred into the target language grammatical constructions (target language) closest, but the words translated lexical still single, out of context.

3. Faithful Translation

In this type of translation, contextual meaning diverted from source language into target language, despite the limitations of target language grammatical structure. Words cultures are transferred and the degree of "abnormality" grammatical and lexical persists.

4. Semantic Translation

This translation is promoting the values the beauty of source language. Translating this model more flexible by providing a space for creativity and intuition interpreter.

5. Adaptation Translation

This type of translation is a form of translation 'most free', commonly used in drama and poetry.

6. Free Translation

In this type of translation, the message and mandate reproduced, regardless of the form in the 
source language. In other words, in this kind of translation, 'content' is translated without following the 'shape' as in source language.

7. Idiomatic translation

In translation this type of message or mandate reproduced in target language but there is a tendency to distortion shades of meaning, due to the use of idiom that was not there at source language.

8. Communicative Translation

In this type of translation, contextual meaning source language diverted so that the message and the language can be received and understood by the target audience of the translation.

\section{Machine Translation}

Machine translation is a blend of linguistics with computational science, often referred to as part of the science of computational linguistic. The point of this science tries to make the machine capable of translating one language into another. Besides proving that the translation is no longer solely a translation by humans, but in a professional context, an improvement of processes and products that combine the power of computers and the analysis of language-based computers with the human ability to analyze the meaning and determine an appropriate form into other languages ,

Based on the Dictionary of Translation Studies (Shuttleworth and Cowic; 1997: 181) Translation is a broad notion that can be understood through a variety of different ways. For example, people will talk about translation as process and product, and recognize each sub kinds as literary translation, technical translation, subtitling and machine translation; furthermore even if the term translation refers specifically to transfer the written text, the term is sometimes also includes interpreting ".

This definition introduces variables more (1) subtypes, which specifically includes not only the writings as the literal translation and technical translation, but also forms a translation that has been created in the last decade, such as audiovisual translation-product written read in conjunction with the images on the screen (cinema, television, DVD or computer game). In the world of translation is known as Google Translate and Rekso Translator. Both of these applications are examples of applications Machine Translation (MT).

Nowadays, there are several types of MT, which is commonly encountered is the Statistical Machine Translator (SMT), Rule Based Machine Translator, and Hybrid Machine Translator. SMT uses statistical calculations to translate a sentence certain language to another language. One status SMT famous example is Google Translate and Microsoft Translator. Because it uses a statistical count, the SMT 
requires examples of existing translations (commonly called bilingual corpora). Example of translation is then calculated chance of a word or phrase is translated into another language. The result of this calculation is to produce a model of translation. Also required sentence examples in both languages (regular called monolingual corpora).Examples of this phrase is used as a language model. This language model is used so that the translation generated a better grammar. The more data translation and data examples of example sentences are the better the results generated translation.

\section{The accuracy of Google Translate}

Google Translate is a service provided by Google Inc. to translate a section of text or web page in one language to another. Google uses its own translation software. Google Translate, like other automatic translation tools, has some limitations. While it can help the reader to understand the general content of a foreign language text, but does not provide an accurate translation.

Google at the beginning of the discovery of a tool or machine that helps Internet surfers to quickly find websites are searched (http://en.wikipedia.org/wiki/google_ translate). This search engine is very useful given the number of web pages in cyberspace could be millions in number, while the human brain's ability to remember the address of a web page is very limited. Google was first developed in 1996 by two students in the United States that Larry Page and Sergey Brin. Currently, Google became the most popular search engine in the world.

Google search engine provides various facilities. In its development, it is not just looking for a web address. Amenities that include image search, video, books, research, scholarship and translator, called Google translator or Google translate. This facility was first developed by Google in 2007 by using a system called SYSTRAN. Google's use of machine translation is easy.

As a machine translator, the results of translated by Google is incomplete and sometimes misleading. The translation can be referred to as pre-translation which still needs to be revised. The translation of machine translators needs to be explored further, especially to see the existing linguistic error, because there is more doubtful quality.

Related to the quality or accuracy of machine translation, Google Translate himself admitted in their website that the most advanced translation engine once now not been able to approach the quality of a native language or do not have the skills of a professional translator. With a firm, Google Translate also 
provides that they will probably take a long time before it can offer a good human translation.

\section{Language Error}

Dulay, Burt, and Krashen explains (1982: 146-197), that in describing the linguistic fault lines can be classified into four categories, namely:
a. Linguistic category
b. Outward strategy category
c. Comparative category
d. Communication affects categories In accordance with the interest of analysis in this study, the categories of errors that are discussed in this study are linguistic category. The description of linguistic fault according to linguistic category is a presentation of errors based on constituent components of language or linguistics. Components include the language phonology, morphology, syntax and semantics.

\section{RESEARCH METHOD}

This research use descriptive qualitative approach. Bogdan and Taylor cited Moleong (2010: 5) define qualitative methodology as a research procedure that produces descriptive data in the form of words written or spoken of people and behaviors that can be observed. While the data is qualitative research in the form of words or pictures, the inductive approach, the goal childbirth theory, emphasizing on the interpretation of social reality, and the intention to understand the meaning of the phenomenon by the participants of a research setting. Qualitative analysis in this study is used to find errors from the translation of narrative text entitled "Snow White" for users of the service Google-translate and classify each of these errors according to linguistic aspects. The approach used is error analysis is done with the following steps: 1) Collect the sample 2) Identifying and classifying errors 3) Sorting error 4) Explains error 5) Correcting errors (Silalahi; 2009: 41).

Basic data used in the form of narrative text in English 'Snow White' is translated into Indonesian by using Google translate service. In this study, researcher used a method refer, by tapping the basic techniques and advanced engineering techniques in the form of free refer ably accompanied by technical log; i.e. researchers only be observers or listeners translation English narrative text 'Snow White' using Google translate, then record the most errors.

The technique used in this research is the analysis technique errors. Working procedures error analysis has measures as proposed by Corder (citied in Nurhadi; 1991: 90), which include:

1. Provision of data in the form of narrative text in English, entitled "Snow White".

2. Identifying of errors.

3. The classification of errors, that is by recognizing and sorting out 
errors based on aspects of language, such as syntax, morphology and semantics.

4. Explanation of error.

5. Evaluating of error.

\section{RESULTS AND DISCUSSION \\ Result}

In this study, according to the data analysis technique used, the linguistic errors in the analysis procedure, the first step that must be done is the provision of data. Below is the data that will be translated by using Google translate, the text of Snow White

(http://www.sekolahbahasainggris.co m/dongeng-snow-white-and-7dwarfs).

A long time ago, a child was born to a queen and king and she was called Snow White. When the queen died, the king married again. This new queen was wicked and hated Snow white. The queen gave orders that Snow White was to be treated as a servant.

Snow White grew very beautiful and one day a Prince riding by, saw her at work and fell in love with her.

The queen was beautiful too, and every day she asked her Magic Mirror, "Who is the fairest in the land?" and the mirror always answered, "You are the fairest one of all".

But one day the mirror answered Snow White was the fairest in the land, and in a rage the queen gave orders to one of her Huntsmen to take Snow White into the woods and kill her.

The Huntsman had a kind heart and couldn't do the deed so told her to run away. She fled into the woods where Seven little dwarfs lived. Their house was small and strange.
Snow White entered the little house and finding it very untidy, started to clean up. Upstairs she found seven little beds. She was very tired and stretching out on one of the beds, was soon asleep.

When the Dwarfs came home they were surprised to find Snow White and after some argument, decided to let her stay. She promised to cook and look after them.

The Queen discovered where Snow White was living and disguising herself as a witch, took a poisoned apple and set out for the Dwarfs cottage. She gave Snow White the poisoned apple to eat and as soon as she bit the apple, she sank into unconsciousness. Thinking she was dead, the Dwarfs built a glass coffin and put her in it. For days she lay in the forest in her glass coffin. One day, the Prince was riding through the forest looking for Snow White and found her. He leaned over and kissed her. She opened her eyes and sat up with a smile. Everyone was happy. The Prince took Snow White to his palace where they were married and lived happily ever after.

Results of narrative text translation "Snow White" on Google translate.

Beberapa waktu yang lalu, seorang anak lahir dari ratu dan raja dan dia dipanggil Putri Salju. Ketika ratu meninggal, raja menikah lagi. Ratu baru ini adalah jahat dan membenci salju putih. Ratu memerintahkan bahwa Snow White untuk diperlakukan sebagai seorang hamba.

Salju tumbuh sangat indah dan satu hari Pangeran naik oleh, melihatnya di tempat kerja dan jatuh cinta padanya.

Ratu juga indah, dan setiap hari ia bertanya Cermin Ajaib, "Siapa yang paling adil di negeri ini?" dan cermin selalu menjawab, "Anda adalah salah satu yang paling adil semua".

Tapi satu hari cermin menjawab Putri Salju adalah yang tercantik di negeri itu, dan dalam kemarahan Ratu member perintah kesalah satu Pemburu untuk mengambil Putri Salju kehutan dan membunuhnya.

8 |Pedagogy - J ournal of English Language Teaching, STAIN J urai Si wo Metro 
The Huntsman memiliki hati yang baik dan tidak bias melakukan perbuatan sehingga menyuruhnya lari. Dia melarikan diri kehutan di manaTujuh kurcaci kecil hidup. Rumah mereka kecil dan aneh.

Salju memasuki rumah kecil dan menemukan itu sangat berantakan, mulai membersihkan. Di lantai atas ia menemukan tujuh tempat tidur kecil. Dia sangat lelah dan peregangan pada salah satu tempat tidur, segera tertidur.

Ketika Kurcaci pulang mereka terkejut menemukan Putri Salju dan setelah beberapa argumen, memutuskan untuk membiarkan dia tinggal. Dia berjanji untuk memasak dan menjaga mereka.

Ratu ditemukan di mana Putri Salju tinggal dan menyamarkan dirinya sebagai penyihir, mengambil apel beracun dan berangkat untuk dwarf pondok. Dia member Salju apel beracun untuk makan dan segera setelah ia menggigit apel, ia tenggelam tak sadarkan diri.

Berpikir dia sudah mati, dwarf membangun peti mati kaca dan menempatkan dia di dalamnya. Untuk hari ia berbaring di hutan di peti gelasnya. Suatu hari, Pangeran naik melalui hutan mencari Putri Salju dan menemukan dia. Dia membungkuk dan menciumnya. Dia membuka matanya dan duduk dengan senyum. Semua orang bahagia. Pangeran mengambil Putri Salju keistananya di mana mereka menikah dan hidup bahagia selamanya.

The identification of errors on the forms of existing faults has been done. After that, the errors were classified by recognizing and sorting out errors based on aspects of language, such as, syntax, morphology and semantics in table form.

The following results table error analysis of the above data:

\begin{tabular}{|c|c|c|c|c|}
\hline $\begin{array}{l}\text { Par } \\
\text { agr } \\
\text { aph }\end{array}$ & $\begin{array}{c}\text { Text } \\
\text { Sources }\end{array}$ & $\begin{array}{c}\text { Google } \\
\text { Translation } \\
\text { Results }\end{array}$ & $\begin{array}{c}\text { The } \\
\text { Correct } \\
\text { Translati } \\
\text { on }\end{array}$ & $\begin{array}{c}\text { Error } \\
\text { Type }\end{array}$ \\
\hline P.1 & $\begin{array}{l}\text { - A long } \\
\text { time ago } \\
\text { - called } \\
\text {-This new } \\
\text { queen }\end{array}$ & $\begin{array}{l}\text {-Beberapa } \\
\text { waktu yang } \\
\text { lalu } \\
\text { - Dipanggil } \\
\text { - Ratu baru ini } \\
\text { adalah }\end{array}$ & $\begin{array}{l}\text {-Pada } \\
\text { zaman } \\
\text { dahulu } \\
\text { - Di beri } \\
\text { nama }\end{array}$ & $\begin{array}{l}\text { Semantic } \\
\text { s } \\
\text { Morpholo } \\
\text { gy }\end{array}$ \\
\hline
\end{tabular}

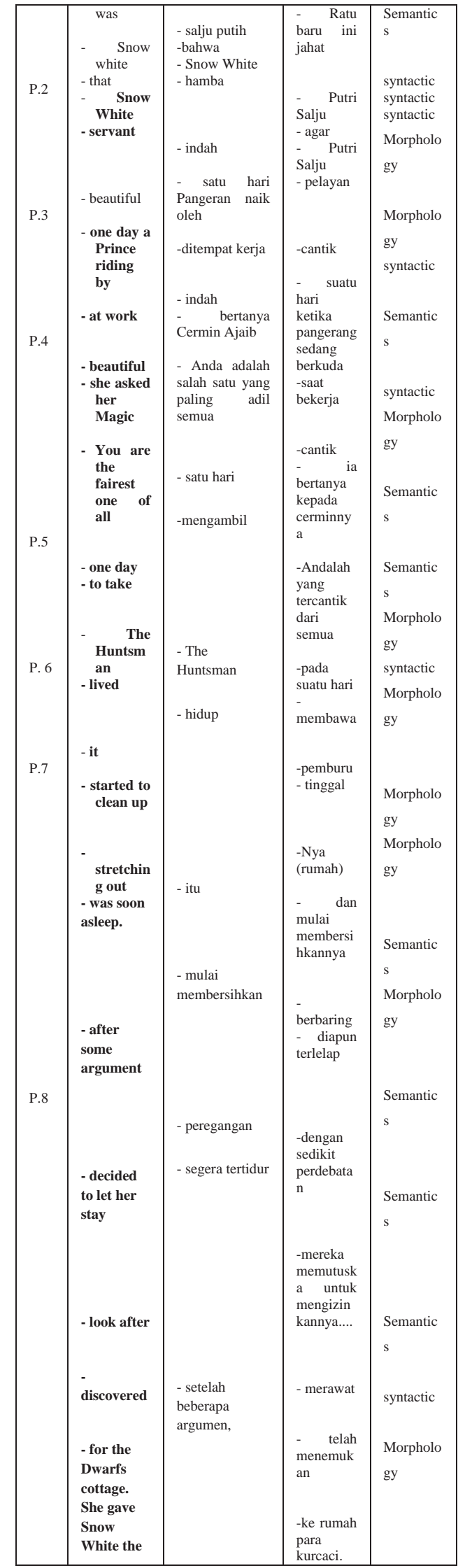




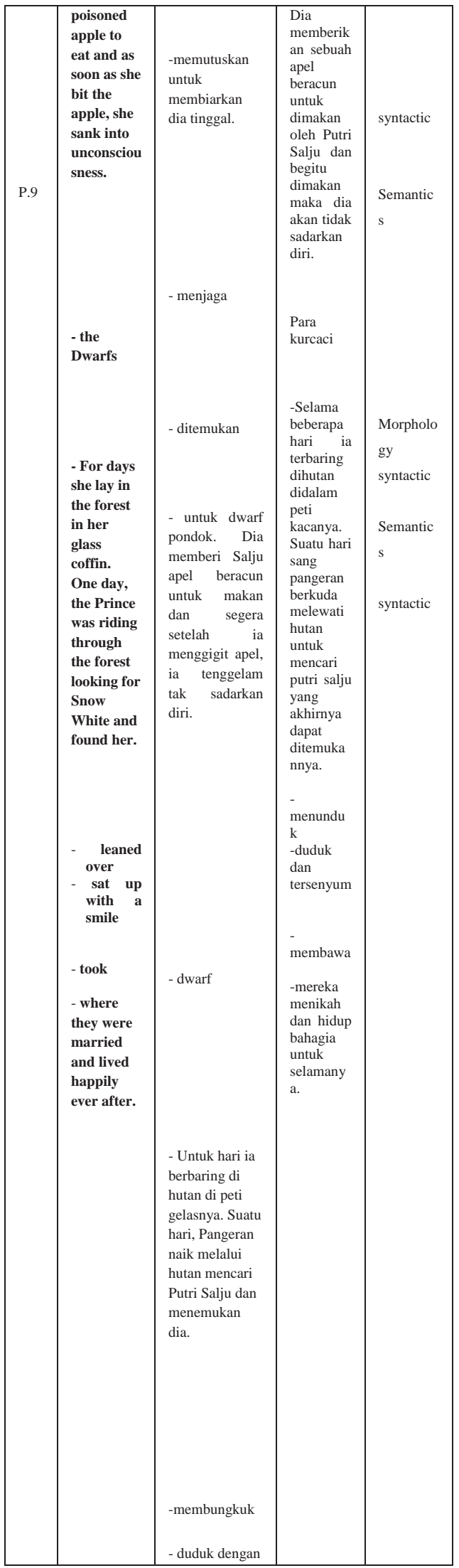

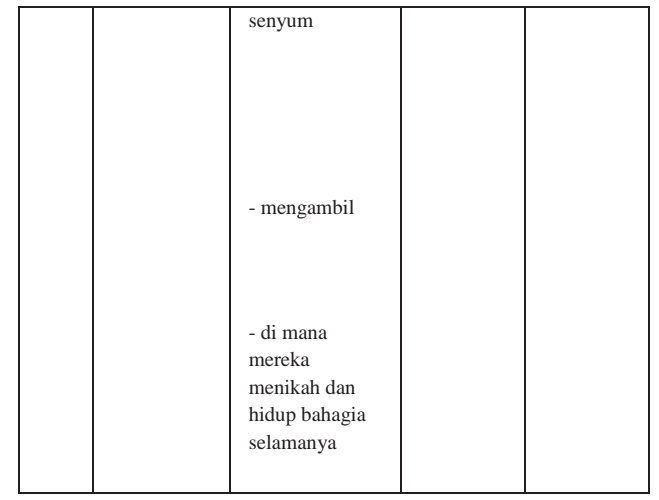

The following are the types of errors found based on the data summary.

\begin{tabular}{|l|c|}
\hline \multicolumn{1}{|c|}{ Error type } & Amount \\
\hline Morphology & 13 \\
Syntactic & 9 \\
Semantics & 12 \\
& 34 \\
\hline Total & \\
\hline
\end{tabular}

\section{Discussion}

Errors of Linguistic Aspects on Translation through Google Translate.

The next step is to explain the error in accordance with aspects of the existing language. There are three aspects used in the error analysis.

\section{Morphology Aspects}

Translation is essentially a transfer of the semantics text source built by vocabularies. Thus, the vocabulary is important in translation, even imperative. Vocabulary forms the basis for building a text to be translated and the translated text.

Morphology is the branch of linguistics that examines aspects of language which are words and their parts. In other words, morphology 
discusses the formation of the word. Linguistic units in the level of morphological form are the smallest linguistic forms, commonly called morpheme.

In the text of Snow White, morphological aspects most commonly found. There were 14 errors that existing in morphology. For example, the word 'beautiful' in terms of significance is appropriate, but in terms of morphology is would be more appropriate if it is translated as 'beautiful'. Likewise with the word 'shop' is used twice in the text. The word means taking, while more precise equivalent for the word with the existing context is the 'carry'. Then the words 'the dwarfts' which remains translated as 'dwarft'. The word should have been translated become after 'the dwarves'. Added the word 'the' because there is suffix -s indicating that the number is plural.

In addition there is the use of the word 'called' translated 'called', of the meaning of translation is appropriate, but in this context it would be worth it if the word used is 'called'. Likewise with the word 'servant' which when translated into 'slave' will be worthy. It is interpreted as 'maids'. At the word 'one day' which was appropriate when interpreted as 'one day' but it would be worthy it if it is defined as 'one day'. Then the word 'lived' which translates to 'live' would be more appropriate in this context if it is defined as 'live'.

\section{Syntactic Aspects}

Syntactic etymologically derived from the Greek, the 'sun' and synonymous with 'tattein' means placing. Therefore, etymologically syntactic means putting together words into groups of words or sentences. Syntactic is the study of how to string words into a sentence based on the creativity and ideas of the author, which is then compiled in accordance with the rules in linguistics. Syntactic includes two things: the study of how words form sentences, and the main points of the rules governing the formation of the structure of the sentence. In English sentences, syntax elements consist of words, phrases, clauses, and sentences. In the syntactic element, the word is the object of study of syntax and sentence, the smallest object of study is the largest syntax.

There are nine errors in the aspect of syntax. The first mistake that the word 'Snow White' which translated as Snow White. While on the other sentences translated as 'snow white'. The next word is 'that' which translated to 'that'. Then the word 'one day a prince riding by' which translated to 'one day the prince by' errors that occurred said this sentence is not only on the aspect of syntactic but also on semantic aspects. Then the word 'at work' are interpreted in the workplace, semantically had been appropriate, but if we look at the context of the discourse of the word is not commensurate with the existing context. No exception to the word 'to take' which translated to the word 'take' the phrase is more worth it if interpreted as the word 'carry'. The next word is 'look after' which translated as 'keep'.

Errors exist a lot on the phrase 'for the Dwarfs cottage. She Gave Snow White the poisoned apple to eat and as soon as she bit the 
apple, she sank into unconsciousness. In the sentence above, errors that occur not only on the aspect of syntactic but also on semantic aspects. Sentence translated by Google translate into 'for dwarf cottage. She gave Snow poisoned apple to eat and soon after he bit the apple, she sank into unconsciousness'. Translation is still a word for word translation that although the meaning of each word is appropriate but can not be interpreted properly because it has not been in accordance with proper grammar.

Just as the next sentence 'For days she lay in the forest in her glass coffin. One day, the Prince was riding through the forest looking for Snow White and found her 'which translates to' four days he lays in the woods in her glass coffin. One day, Prince riding through the woods looking for Snow White and found him. Errors that occur are also not only in the aspect of syntactic but also on aspects of semantics. It would be worth it when it is translated as' For several days he lay in the forest in the glass coffin. One day the prince rode through the forest to look for the snow princess who finally can be found.

\section{Semantics Aspects}

The word semantics agreed as a term for the science language to discuss and learn about the meaning or significance. There is some argument about the kinds of meaning. There is some argument about the kind of meaning. The following are among the types of meanings, including lexical meaning can be interpreted as meaning the word loosely outside the context of the sentence.
Lexical meaning is mainly in the form of words in the dictionary, which are usually the first meaning of the word or the entry listed in the dictionary. While the meaning of grammatical meaning is the meaning that arise as a result of malfunction of the word in a sentence. Grammatical meaning is what is emerging as a result of a grammatical process. Contextual meaning is the meaning derived from the linguistic environment that surrounds a word, phrase or sentence. Contextual meaning is also based on social condition, situation or place and circumstances and occasions where the word or phrase was uttered with all its elements, either from the speaker or the listener. That's why many experts say that a new word can be determined meaning, if it has been said in the context of the sentence.

Errors on semantic aspects occur as many as six. Beginning with the introduction of 'Once upon a time' which translated to 'some time ago' translation is not appropriate to the context used in the target language for the appropriate word used in fairy-tale opening in the target language are the days of yore. So in this case it would be worthy it if it translated to 'once upon a time'.

Then in clause 'one day a Prince riding by', which is not only one of the semantic aspects but also on aspects of syntax, just as described in the aspect of syntax. Likewise the phrase 'for the Dwarfs cottage. She Gave Snow White the poisoned apple to eat and as soon as she bit the apple, she sank into unconsciousness'. Then in the 
sentence 'For days she lay in the forest in her glass coffin. One day, the Prince was riding through the forest looking for Snow White and found her '. And the sentence at the end of the paragraph that 'where they were married and lived happily ever after.' Errors that occur not only on the semantic level but also at the level of syntax.

Then in clause 'one day a Prince riding by' who is not only one of the semantic aspects but also on aspects of syntax, just as described in the aspect of syntax. Likewise the phrase 'for the Dwarfs cottage. She Gave Snow White the poisoned apple to eat and as soon as she bit the apple, she sank into unconsciousness'. Then in the sentence 'For days she lay in the forest in her glass coffin. One day, the Prince was riding through the forest looking for Snow White and found her '. And the sentence at the end of the paragraph that 'where they were married and lived happily ever after.' Errors that occur not only on the semantic level but also at the level of syntax.

Errors that occur on semantic aspects mostly due to the translation done by google translate only recognize or denotative lexical meaning alone. The text used in this study is that the mythical narrative text. Each country has the usual fairy tale into children's literature. Because usually the language used is not too difficult to be translated into other languages. Related to the translation, the meaning of which is produced normally have to be adjusted or matched to the target language. The cultural context plays a very important in this regard beside linguistic context of course.

Thus, the context of linguistic and cultural context is very important in meaning. The definition of the linguistic context is a collection of sounds, words, and sentences that can be delivered on a particular meaning, or the entire state, condition, and linguistic elements that surround a word. While the definition of cultural context are the cultural values and social bladder by a word or phrase, it is associated with a particular culture and society.

By reviewing briefly the translation of the English text into Indonesian by Google's machine translation. It is found that this machine translates word by word, sentence context is often overlooked. This aspect is a major weakness of the translation results obtained through Google's machine translation. Therefore, users who want to translate a text must make improvements to the text of the translation.

\section{CONCLUSION}

Google Translate service in translating English text into Indonesian on the type of narrative text showed that the morphological aspects occupy the highest positions in the data summary types of errors, as many as 13 errors. Next is the syntactic aspect for 9 errors, and morphology of with 12 errors.

It can be concluded that the translation using Google Translate is not the right solution for someone who wants to translate foreign language text. Google Translate is only a pre-translation which still 
needs a lot to be revised, especially from all kinds of linguistic aspects.

\section{SUGGESTION}

It is recommended to teachers, especially to good English teacher at secondary level and upper level who are accustomed to using Google Translate to be more careful in using it as an alternative means of translation assistance so that the results will not have any linguistic errors.

\section{REFERENCES}

Catford, J.C. 1965. A Linguistic Theory of Translation: An Essay in Applied Linguistics. London: Oxford University Press.

Heidi C. Dulay, Marina K. Burt, Stephen D. Krashen. 1982. Language Two. Oxford University Press.

$\begin{array}{lr}\text { Hoed, Benny } & \text { Hoedoro. } \\ \text { 2006. Penerjemahan } & \text { dan } \\ \text { Kebudayaan. Jakarta: } & \text { Pustaka } \\ \text { Jaya } & \end{array}$

http://en.wikipedia.org/wiki/google_t ranslate.

http://www.sekolahbahasainggris.co $\underline{\mathrm{m} / \text { dongeng-snow-white-and-7- }}$ $\underline{\text { dwarfs }}$

Lado, R. 1968. Linguistics Across Culture: Applied Linguistics for Language Teacher. An Arbor: University of Michigan Press.
Larson, M.L, 1984. Meaning-Based Translation: A Guide to CrassLanguage Equivalence. Boston: University Press of America.

Moleong.2010. Metodologi Penelitian Kualitatif. Bandung: PT Remaja Rosdakarya.

Newmark, Peter. 1988. A Textbook of Translation. Hertfordshire: Prentice Hall International.

Nida, Eugene Aand Taber, Charles R. 1969. The theory and Practice of Translation.Leiden: E. J. Brill

Nurhadi, Roekhan.1990. Dimensidimensid.alamBelajarBahasa Kedua. Bandung: SinarBaru.

Shuttleworth. M, , and Cowie.M. 1997. Dictionary of Translation Studies Manchester: St Jerome Publishing.

Silalahi, Ulber . 2009. Metode Penelitian Sosial .Bandung: PT Refika Aditama. 